\title{
RAISING CAPITAL FOR MICROFINANCE: SOURCES OF FUNDING AND OPPORTUNITIES FOR EQUITY FINANCING
}

\author{
David Fehr ${ }^{*}$ \\ Assistant Professor - Economics/Finance \\ Director - Center for Financial Studies \\ Southern New Hampshire University \\ Gaamaa Hishigsuren \\ PhD Candidate \\ School of Community Economic Development \\ Southern New Hampshire University
}

Working Paper No. 2004-01

(C) 2004 David Fehr and Gaamaa Hishigsuren

* Please direct all inquiries and correspondence to David Fehr at d.fehr@snhu.edu or 603-644-3197. We would like to thank the School of Business, Southern New Hampshire University for support. We take credit for all errors that remain. Working Papers are a series of manuscripts in their draft form, and reflect the view of the author(s), not Southern New Hampshire University or the Center for Financial Studies.

NOTE: A revised version of this paper has since published at:

Fehr, D.W., and Hishigsuren, G. (2006). Raising capital for microfinance:

sources of funding and opportunities for equity financing. Journal of

Developmental Entrepreneurship, 11 (2), pp. 133-143. 


\section{Table of Contents}

I. Introduction

II. Sources of financing
A. Donor grants
B. Savings
C. Private sector capital
D. Evolution of microfinance financing
E. Innovative financing mechanisms

III. Strategies for raising equity capital
A. Traditional approach
B. Financial analysis approach

IV. Summary and conclusion 


\section{INTRODUCTION}

Microfinance has been spread around the world as a popular poverty reduction strategy. In 1997, the Microcredit Summit Campaign was launched with the goal of servicing 100 million of the world's poorest households. This is in line with the Millennium Development Goals, agreed to at the United Nations Millennium Summit, which set a challenging goal of halving the absolute poverty in the world by 2015 .

Micro-finance has a high potential to contribute to these Millennium Development Goals. As of December 2000, about 1600 microfinance institutions reported to the Microcredit Summit that more than 19 million of the poorest households around the world have access to financial services. However, this leaves 81 million of the world's poorest people to be reached before the Campaign target of 100 million is achieved. If only 10 percent of the 1580 microfinance institutions (MFIs) that reported to the Microcredit Summit could be scaled up to serve an average of 500,000 very poor households each, then the shortfall of 81 million could be overcome. However, without capital to cover its operations, to finance its lending operations, and to leverage financial resources from commercial institutions, it is unlikely that microfinance institutions would be able to achieve this objective.

Many pioneering MFIs all over the world have proven that they can deliver financial services to individuals and businesses that otherwise would not have access to financial services. However for many of these MFI's, the dependence on donor funds increasingly constitutes an obstacle to growth, and thus they are now turning to other, commercial sources of funds. The shortage of capital creates two major, interrelated problems for MFIs: (1) slower than optimal rates of growth due to shortage of funds, and (2) large operational deficits prior to institutional financial breakeven, which itself tends to limit optimal growth rates. These operating deficits limit MFI access to capital, even at market rates. While there is an undeniable need for MFIs to access capital that would enable them to make a greater contribution towards poverty-reduction, commercial lenders and equity investors (whether private, public or hybrid) have difficulties in identifying viable microfinance investments, or do not yet see microfinance with the poor as a potentially profitable investment opportunity. This raises a key question: How can MFIs effectively communicate their prospects to potential mainstream investors?

Section II of this paper examines the typical sources of financing for microfinance, followed by a discussion regarding the current practices of MFIs in raising capital. To date, funding of MFI activities has come primarily from outright donor grants, government subsidies, and often debt capital, including debt with non-market terms favorable to the MFI. Clearly, each funding source embraces charitable motives to support the beneficial poverty reduction strategies of the MFI. However, especially in the current worldwide economic environment, these traditional sources of MFI financing may not be sufficient to allow MFIs to provide maximum services. As such, MFIs are interested in approaching new classes of potential investors for participation in MFI projects. The purpose of this section is to motivate a discussion for the potential use of equity capital in MFI financing by presenting the strengths and weaknesses of each 
financing option. We will also highlight operational aspects of MFIs that could impact capital raising opportunities.

Section III begins with a brief review of the traditional narrative approach to fundraising. We then outline classical finance techniques that could be used by the MFI to approach mainstream equity investors. There is, almost certainly, a subset of this investor pool which would consider investing in MFI opportunities, even knowing that they would not expect to earn the full economic rate of return that such investments would otherwise require. That is, these investors may be willing to accept a reduced rate of return on investment (ROI), in order to satisfy social motives that they may have. However, as part of their investment evaluation process, these investors would ask:

- What would the market determined required expected rate of return for my MFI investment be?

- What ROI do I expect to earn on my MFI investment?

- Is the difference in the above two returns acceptable given my level of social motivation?

- How will I "monetize" my investment and when?

- What are the cash flows available to me in this project?

Modern corporate finance provides directed techniques and analytical procedures to address these questions. However, in preparing information for individual donors and government agencies, MFIs tend to emphasize descriptive documentation and have no need to address the above questions directly. The purpose of Section III is to apply modern finance techniques to this important situation. How would the MFI best organize its data, analyses and presentation to attract mainstream equity investors? We will propose an analysis based on expected cash flows available to equity holders.

Finally, Section IV summarizes our conclusions and sets the stage for the field work that would be necessary to implement our recommendations.

\section{SOURCES OF FUNDING}

\section{A. Donor and government grants and soft loans}

Microfinance has received significant attention from the donor community, based upon its potential as a powerful tool for poverty alleviation. As such, many millions of dollars have been spent on promoting microfinance programs around the world. For most MFIs, the principal source of funding is from grants and highly subsidized loans, or socalled soft loans. Soft loans are obtained from multilateral banks (e.g., the World Bank, Inter-American Development Bank alike), government aid agencies (e.g., United States 
Agency for International Development (USAID), UK Department for International Development (DFID), foundations (e.g., Ford Foundation) and apex organizations (e.g., Women's World Banking, ACCION, FINCA). Usually such grants and soft loans include conditions and requirements as to how the funds should be spent and are in limited dollar amounts. However, most would agree that in order to achieve the goal of reaching the remaining 81 millions poorest households, MFIs would need to access capital above and beyond grants and soft loans.

\section{B. Savings}

Historically, deposits (demand deposits, passbook savings, time deposits, certificates of deposits and the like) have been a primary source of funds for financial institutions. Hempel and Simonson (1999) have reported that, for US commercial banks, $97 \%$ of their total liabilities are made up of demand deposits and time deposits. Clearly, these savings accounts fuel the lending operations of the banks. Furthermore, Wisniwski (1999) reports that this has been true irrespective of the regional or cultural context in which the banks or related non-bank financial institutions have developed.

However, in most developing countries, especially in South, East and Central Asia, MFIs are not permitted to re-deploy depositor savings until they can meet certain minimum capital requirements mandated by regulatory authorities. Unfortunately, such capital adequacy requirements are typically not met until the MFI is a mature institution, thereby precluding if from taking advantage of the potential leverage provided by these deposits. We will explore this issue in more detail below.

\section{Private Sector Capital}

During the last decade, the microfinance community has recognized the limitations of donor and government subsidies in reaching a significant scale and scope of operations. As many microcredit programs apply the so-called graduation principle in their lending operations, increasing the size of repeat loans according to their repayment record of previous loans, it is essential to raise/attract sufficient funds to sustain this process.

Thus, many MFI's are moving away from donor funding into the more traditional sources of capital financing that typical corporations use. Debt capital is often a first choice, either in the form of borrowings from commercial and central banks, or when capital markets are well-developed, long term debt instruments. Hannig and Wisniwski (1999) point out that these debt obligations are attractive to both sides of the transaction, as they not only provide a steady source of income for the owners, but it also provides a stable source of funds for the issuers.

Equity, which is the focus of this paper, is another potential source of capital. In fact, certain quasi-equity structures are in current use: 
- Donations to the MFIs can be thought of as an equity investment, although the donor does not expect to receive a return on investment (ROI) or other monetary return

- Apex organizations or Non-Governmental Organizations (NGOs) typically provide capital when they take an ownership position

- Venture capital funds, enterprise equity funds or quasi-equity investment funds

- Equity-like subordinated debt

- Private placement funds

- Limited partnerships or limited liability company participation

- Institutional or individual investors interested in social returns

Clearly, none of the above represents equity as typically characterized by the financial community. Classical equity investors would require some ROI in the form of future cash flow receipts. Furthermore, many of the participations taken by the funds, partnerships and social investors above have characteristics more closely resembling debt than equity, namely, contractually bound repayment programs.

\section{Evolution of microfinance financing}

To illustrate a financing chronology moving toward equity financing, consider Table 1 below, a modified table from Calvin (2001). Typical sources of financing are linked with four (4) representative stages of MFI evolution. Donor grants and soft loans comprise the majority of the funding in the formative stages (Start-up, Operational Selfsufficiency) of the organization; the early stage MFI will almost surely not qualify for commercial funding of any kind. As the MFI matures to Financial Self-sufficiency, private debt capital becomes available. As we will describe below, the debt structures are often laden with restrictive covenants and often must have guarantees attached. It is only in the last stage of MFI evolution that traditional equity financing will be appropriate. In Section III, we will outline procedures that the MFI might employ to employ Calvin's last financing category: commercial equity.

Wisniwski (1999) points out that, during the early stage when subsidized funding predominates, the lack of clear ownership can distort incentive structures and undermine sustainability of the enterprise. This "moral hazard" problem is well known in the finance literature and has motivated considerable research on the agent/principal issue; see Jensen and Meckling (1976) for the seminal work. In essence, when costless verification of agent activities is impossible, principals will need to establish incentive arrangements for agents to eliminate the moral hazard and/or consume resources to monitor the activities of and to direct agents. Recent literature has explored implications of organizational structure, prototype incentive programs and various monitoring strategies on the agency problem; see for example Glaeser and Schleifer (1998) and Fehr (2003).

Furthermore, note that in the case of the early stage MFI, it may even be unrealistic to find a fully engaged principal in the agent/principal relationship. The 
typical donor is unlikely to monitor the activities of the MFI to the same extent as a commercial investor anticipating a financial return. So then, another advantage to introducing equity into the capital structure of the MFI would be to introduce more discipline into operational activities and manager behavior.

As the enterprise progresses through Stages II and III, commercial loans become increasingly relevant for mature Non Governmental Organizations (NGOs). Properly structured, these vehicles can become a continuous source of reliable funding. Furthermore, these commercial loans begin to provide appropriate incentives and discipline to MFIs with the use of restrictive covenants. Also, MFI mangers will begin to learn that good governance and management performance are important prerequisites for ongoing access to the capital market. Note however, many jurisdictions require that commercial loans must be backed by third-party guarantees. This issue will be discussed below.

Table 1: Evolution of MFI financing

\begin{tabular}{|l|c|c|c|c|c|c|}
\hline & $\begin{array}{c}\text { Stage } \\
\text { I: } \\
\text { Start- } \\
\text { Up }\end{array}$ & $\begin{array}{c}\text { Stage II: } \\
\text { Operational } \\
\text { self- } \\
\text { sufficiency }\end{array}$ & $\begin{array}{c}\text { Stage III: } \\
\text { Financial Self- } \\
\text { sufficiency }\end{array}$ & \multicolumn{2}{|c|}{$\begin{array}{c}\text { Stage IV: Commercial } \\
\text { level Return }\end{array}$} \\
\hline NGO & NGO & NGO & $\begin{array}{c}\text { Licensed } \\
\text { financial } \\
\text { institution }\end{array}$ & NGO & $\begin{array}{c}\text { Licensed } \\
\text { financial } \\
\text { institution }\end{array}$ \\
\hline Donor & & & & & & \\
\hline Grant and soft loans & $\mathrm{x}$ & $\mathrm{x}$ & $\mathrm{x}$ & $\mathrm{x}$ & $\mathrm{x}$ & $\mathrm{x}$ \\
\hline Internal & $\mathrm{x}$ & $\mathrm{x}$ & $\mathrm{x}$ & & $\mathrm{x}$ & \\
\hline Forced savings & & & & $\mathrm{x}$ & & $\mathrm{x}$ \\
\hline Voluntary savings & & & & & & \\
\hline Private & & & & & & \\
\hline Debt & & $\mathrm{x}$ & $\mathrm{x}$ & $\mathrm{x}$ & $\mathrm{x}$ & $\mathrm{x}$ \\
\hline Commercial loans & $\mathrm{x}$ & $\mathrm{x}$ & $\mathrm{x}$ & $\mathrm{x}$ & $\mathrm{x}$ \\
\hline Guarantee funds & & & $\mathrm{x}$ & $\mathrm{x}$ & $\mathrm{x}$ & $\mathrm{x}$ \\
\hline Bonds & & & $\mathrm{x}$ & $\mathrm{x}$ & $\mathrm{x}$ & $\mathrm{x}$ \\
\hline Securitization & & & & $\mathrm{x}$ & & $\mathrm{x}$ \\
\hline Inter-bank borrowing & & & & & & \\
\hline Equity & & & $\mathrm{x}$ & $\mathrm{x}$ & $\mathrm{x}$ & $\mathrm{x}$ \\
\hline Quasi-equity & & & $\mathrm{x}$ & $\mathrm{x}$ & $\mathrm{x}$ & $\mathrm{x}$ \\
\hline Retained earnings & & & $\mathrm{x}$ & $\mathrm{x}$ & \\
\hline Socially responsible equity & & & & & $\mathrm{x}$ & $\mathrm{x}$ \\
\hline Commercial equity & & & & & \\
\hline
\end{tabular}

When an NGO's reaches Stage III, it typically begins to realize some retained earnings and is in a position to access quasi-equity. Quasi-equity refers to medium to 
long term, soft, subordinated loans which are designed to be repaid out of profits after institutional financial break-even. Again, this vehicle is more analogous to a structured debt offering than a standard equity structure. Also, at Stage III, we observe NGOs beginning to make use of asset securitization.

As the NGO progresses through Stage III, it can be transformed into a regulated financial institution. A primary advantage of this transition is that the regulated financial institutions can access voluntary client savings in most jurisdictions. As we have reported previously, client deposits have been a dominate source of funding for traditional financial institutions. During the last decade, the appropriateness of this funding source has become the focus of heated discussions among the microfinance community, see for example Otero (1989) and Hannig and Wisniwski (1999). There are at least three benefits to savings mobilization from the MFI perspective:

- Financial self-sufficiency of the institution is fortified - savings represent a relatively stable and cheap source of funds

- Dependency on external borrowing is reduced, allowing the institution to engage in community-based operations of its choice as opposed to the priorities of the lender, especially when the lender is a governments or donor agency

- Saving services are more likely to be provided to the poor when mobilization provides an incentive to establish savings accounts

In addition to the ongoing discussion of the appropriateness of savings mobilization, there is a significant amount of literature on the relationship between savings and other sources of capital. For example, Gadway and O'Donnell (1996) argue that locally mobilized savings are an ideal funding source for MFIs. Otero (1989) proposes a gradual shift for MFIs away from donor grants and soft loans as funding sources to commercial sources of funds and, eventually, to public deposits. She states that at an advanced stage of institutional evolution, savings mobilization will provide the largest share of capital. In a similar vein, Jackelen and Rhyne (1991) argue that continuous support from the donor community leads MFIs to become highly dependent on subsidies and thereby discourages them from becoming a competitive and selfsufficient financial intermediary. With a more skeptical point of view, Schmidt and Zeitinger (1996) argue savings mobilization costs and risks may be material, and as such, alternative financing is preferred.

Stage IV characterizes NGOs and financial institutions that are beginning to achieve a significant level of retained earnings. At this stage, the institution should be in position to attract both socially responsible equity and commercial equity so, in theory, its growth opportunities should be vastly expanded, Calvin (2001). 


\section{E. Innovative financing mechanisms}

As Private Sector Involvement Working Group of Consultative Group to Assist the Poorest (CGAP) stated in 1996, "There is a long way to go before MFIs can attract serious financial support from capital markets. We're on the very beginning of the learning curve. Creative efforts are now required to further develop financial instruments to facilitate the mobilization of funds for microfinance." Financial instruments that have become more widely used in practice since that 1996 pronouncement include:

\section{Credit Guarantees}

A credit guarantee is a financial instrument that encourages financial institutions to lend to retail microfinance institutions and/or directly to microenterprises that have good prospects of success, but are unable to provide sufficient collateral or do not have a suitable record of financial transactions, Bass(2000). The guarantee functions as a promise by a guarantor to the lender that, in the event that the borrower defaults, the guarantor will repay the lender. An ancillary benefit to this guarantee activity is to familiarize banks with the client and, in this process, induce banks to lend to clients that otherwise would not eligible for bank credit.

There are a growing number of guarantee schemes funded by multilateral donor agencies and financial institutions. For example, USAID set up a loan portfolio guarantee (LPG) program for the Compagnie Bancaire de l'Afrique Occidentale (CBAO) in Senegal, and the International Finance Corporation (IFC) launched a Global Credit Enhancement Facility (GCEF) in Fall, 2001. Also, under the Micro and Small Enterprise Development Program, USAID has used innovative financial instruments including guarantees to facilitate lending to buyers of MFIs.

In setting a credit guarantee program, the guarantor will want to set the fee structure based on the costs of monitoring and information gathering as well as the cost of the risk transfer service provided. It can often be difficult to establish a viable fee structure that fully compensates the guarantor for the services provided, Bass (2000). The agency issue is also present in that the lender's interest in carefully screening clients and following up on delinquent loans is diminished with the introduction of the guarantee.

\section{Securitization}

Securitization is another innovative attempt to link microenterprises with capital markets. Typically, this structure requires the creation of a single purpose corporation (SPC) that buys the microenterprise portfolio and capitalizes itself by issuing debentures for the capital market.

Mr. Michael Chu, former President and CEO of ACCION International, has said, "With the right partner, securitization can create an alternative microenterprise finance system that deals with the capital markets, in the language of the capital markets, in a market for which the capital markets are not suited." For example, ACCION International and its affiliate, Fundacion Ecuatoriana de Desarrollo (FED), piloted 
securitization in Ecuador. He explained: "SPC's equity of approximately $\$ 2$ million will come from FED, a local financial partner, ACCION International (through the Gateway Fund), and others. The SPC uses its cash to purchase \$105 of portfolio from FED; but it pays FED $\$ 100$ and puts the remaining $\$ 5$ in a reserve which it pays on collection of the loan. This reserve amounts to roughly $5 \%$ of the portfolio that it purchased, so the SPC is protected by five times the historic rate of default of the portfolio. In addition, the SPC has \$2 million dollars of equity, so anyone who buys paper issued by the SPC is highlyprotected. It is projected that this structure will receive an AAA rating from the rating agencies."

\section{Debt instruments}

There are a few initiatives to issue debt instruments in microfinance. Bancosol, a microfinance institution in Bolivia, has issued certificates of deposit, which trade on the Bolivian stock exchange. Bancosol has also issued long-term debt instrument partially guaranteed by the USAID fund. Senior management of Bancosol has stated that the institution will continue to reduce its reliance on expensive interbank loans through the issuance of bonds and certificates of deposit. Over time, the hope is that savings mobilization will assume an ever larger proportion of funding.

In Paraguay, ACCION's affiliate Fundacion Paraguaya, as an NGO, issued a debt instrument through the securities exchange of Paraguaya. Before issuing the paper, ACCION conducted a formal analysis employing a variant of an assessment tool used by bank examiners in the United States. The rating from this analysis coupled with a clearly articulated business plan was important in the debt issuance process. In exploring the use of equity capital for MFIs, we will argue that financial analyses and data of these types will be necessary.

\section{Specialized equity funds}

Specialized equity funds such as Profund, DEVCAP and AfriCap, created with donor support, take equity stakes in MFIs, Silva (1998). Each of these vehicles has a unique structure, size and geographical focus - Profund focuses on Latin America and Caribbean, AfriCap focuses on Africa, while DEVCAP was established to support micro

enterprise lending by four U.S. development agencies (Save the Children, Catholic Relief Services, Appropriate Technology International and SEED Capital Development Fund) that support MFIs in 54 countries. These commercial investment funds focus on social returns, understanding that the financial returns will likely be below the appropriate risk adjusted market rate.

These donor-supported funds are complemented by similar equity investments made by international investment companies. For example, The Triodos-Doen Foundation, founded in 1994, provides equity capital to MFIs all over the world in addition to loans and loan guarantees. The Calvert Targeted Community Investments and the Internationale Micro Investitionen Aktiengesellschaft (IMI) have similar equity investment programs. 
In conjunction with MFI forays in the commercial capital markets, rating agencies that analyze MFIs for commercial investors have come into being and have also attracted donor interest. For example, the Inter-American Development Bank (IDB) and the Consultative Group to Assist the Poorest (CGAP) are launching the pilot phase of a joint initiative called the Microfinance Rating and Assessment Fund (MRAF). An objective of the Pilot Rating and Assessment Fund is to build a supply of competent ratings and appraisal services by supporting organizations that perform high-quality assessments, particularly agencies in developing countries. A secondary objective is to build a reliable database on different types of MFIs around the world that can serve as a reference point for donors, investors, banking supervisors, and MFIs themselves (CGAP2). A longerterm goal of this initiative is to enable a greater flow of private sector resources to the microfinance sector by improving the quality, availability, and frequency of information on the risk and performance of MFIs, CGAP2(2001).

\section{STRATEGIES FOR RAISING CAPITAL}

\section{A. Traditional Approach}

As a poverty reduction vehicle, microfinance has attracted large sums of donor grants and subsidies. The traditional approach to raising capital from donors and philanthropy sources often begins with a proposal that includes descriptive information in a narrative form. In particular, a typical proposal requesting funding from donors or philanthropy includes background information of the organization, its current or proposed products and services, a target clientele, expected social benefits and the amount of funding required. The expected returns to potential investors are usually described in terms of the number of poor people to be served, and the types of impact it will have on the lives of the poor. A three-year project "Assessing the Impact of Microenterprise Programs" (AIMS), funded by United States Agency for International Development (USAID), presents a framework for evaluating the impact of micro-finance programs along these lines. ${ }^{1}$ This framework has become widely used by many micro-finance programs in reporting their social returns. The framework posits that impact occurs at the following levels:

- At the family/household level, microenterprises contribute towards a net increase in family/household income, asset accumulation, and labor productivity. Income invested in assets such as savings and education increase family/household economic security by making it possible to meet basic needs when the flow of income is interrupted.

- At the enterprise level, the impact is represented by changes in income, employment, assets, and volume of production.

\footnotetext{
${ }^{1}$ For more detailed discussion about this framework, check the publications at http://www.mip.org under AIMS.
} 
- At the individual level, change is measured by the clients' capacity to make decisions and investments that improve business performance and personal income, which in turn strengthens the family/household economic portfolio and often translate into personal empowerment.

- At the community level, microenterprises can provide new employment opportunities, stimulate backward and forward linkages to other community enterprises, and attract new income from outside the community. To the degree that the poor benefit from such increased economic activity, microenterprise interventions can have additional equity impacts.

These relationships clarify paths of impact by which microenterprise interventions can contribute to the goals of poverty alleviation and economic growth:

- Family/households improve their economic security;

- Enterprises become more stable and even grow;

- Individuals increase their control over resource allocations and improve their well-being; and

- Communities develop economically through enterprise activity that provides goods and services, attracts income, and creates jobs.

To assess change within these pathways or relationships, the framework defines "domains of impact" at each level. Within each domain, markers of change, or indicators, are identified to measure impact. For example, at the level of the enterprise, financial change can be measured by changes in income or business assets. These markers of change can function alone as an indicator of impact, or they can be assessed in combination to capture such things as (1) the movement of family/households toward (or away from) greater economic security, (2) the progression of enterprises between stages of development, (3) changes in individual well being, and (4) changes in community development.

Only a very few microfinance organizations provide audited financial statements. As was described in one of the viewpoints published by the Consultative Group to Assist the Poor (CGAP), a frustrated investor's tale reads:

An investment banker expressed exasperation at the response of NGO MFIs to requests for basic financial reports and information. She was often told either that such reports were unavailable, or was provided with incomplete or unreliable data. She had gone out on a limb to broaden her bank's options to include NGO MFIs, but they had been unable to respond appropriately. "This is precisely the type of behavior that helps contribute to a perception among investors that NGOs are not serious players in micro finance," she concluded (Pearce, 2002). 


\section{B. Financial Analysis Approach}

The purpose of this section is to demonstrate the financial procedures that a mainstream equity investor would use to evaluate an MFI equity investment. The investor will be most concerned with the package of cash flows, generated by the MFI, which will be available. The MFI should assume that the investor will attempt to estimate the amount and timing of cash flows that will be available to provide his/her return on investment. In soliciting equity participation from investors, the MFI would be well served to provide this data as part of the offering circular.

We will assume that the MFI collects financial and operating data typically required to prepare accounting statements. Whether or not the statements actually get produced is not crucial for our analyses, since that data would need to be modified anyway. However, we would certainly recommend that the MFI produces the full range of accounting statements. Clearly, the investment community will react more favorably to an enterprise with financial reporting and control procedures in place.

In evaluating his/her potential equity investment in the MFI, the investor will discount cash flows available to the equity holder at a market determined required expected rate of return for investments of the given risk level. The present value (PV) of these cash flows will be compared to the level of the initial equity investment. If the PV exceeds the initial investment, this investment opportunity would be a desirable investment project. Stated alternatively, the net present value (NPV) of the investment project would be greater than zero, and the project should be undertaken. Refer to any standard financial management text, e.g., Brealey and Myers (2001), and references therein to review the NPV apparatus and its applicability for project selection.

However, an NPV $>0$ scenario is not what we would expect in the microfinance setting. It is likely that, for most MFI equity investment opportunities, the PV of equity cash flows will be less than the initial investment. In classical project analysis, such an investment would be rejected as unacceptable. In our case, we can view the difference between the amount of initial investment and the PV of cash inflows as a measure of the socially beneficial contribution (donation) made to the enterprise by the provider of capital. For investors who prefer to evaluate the investment in terms of rate of return, we will provide a procedure using the internal rate of return (IRR) method.

Let

$$
\begin{aligned}
\mathrm{E}_{0}= & \text { equity investment at time } \mathrm{t}=0 \\
C F E_{i}= & \text { cash flow available to equity at time } \mathrm{t}=\mathrm{i}, \mathrm{i}=1,2, \cdots \infty \\
\mathrm{k}_{\mathrm{i}} \quad & \text { required expected return on equity during the ith time period; } \\
& \text { note that many standard analyses estimate } \mathrm{k} \text { to be constant during } \\
& \text { the investment horizon, but we will describe a case below in } \\
& \text { which it is may be more productive to work with different } \\
& \text { required returns through time }
\end{aligned}
$$




$$
\mathrm{IRR}=\text { internal rate of return on the investment }
$$

The relevant calculation for the equity investor is

$$
\begin{aligned}
& \mathrm{NPV}=-\mathrm{E}_{0}+\sum_{i=1}^{\infty} \frac{C F E_{\mathrm{i}}}{\left(+\mathrm{k}_{\mathrm{i}}^{\mathrm{T}}\right.} \\
& \text { If } \mathrm{NPV}>0 \text {, we have that } E_{0}<\sum \frac{C F E_{\mathrm{i}}}{\left(+\mathrm{k}_{\mathrm{i}}{ }^{\mathrm{i}}\right.}
\end{aligned}
$$

This situation represents the commercially viable investment which the investor would choose to undertake even without a socially motivated desire. If

$$
E_{0}<\Sigma \frac{C F E_{i}}{\left(+\mathrm{k}_{\mathrm{i}}^{\top}\right)}
$$

then

$$
E_{0}-\sum \frac{C F E_{i}}{\left(+\mathrm{k}_{\mathrm{i}}{ }^{\top}\right.}
$$

represents that portion of the initial $\mathrm{E}_{0}$ investment that is effectively a socially motivated donation.

In order to calculate the NPV, it will be necessary to:

- $\quad$ Estimate $C F E_{i}$ for all i

- $\quad$ Estimate $\mathrm{k}_{\mathrm{i}}$ for all $\mathrm{i}$

- $\quad$ Employ a terminal value procedure to make the infinite sum in the NPV calculation tractable

For demonstration purposes in this paper, we will assume that the potential equity investor has established an estimate for his/her required expected return, $\mathrm{k}$. This assumes that the investor has (1) established a market determined required expected rate of return for equity investment with the same risk characteristics as the MFI, and (2) is satisfied in working with a constant $\mathrm{k}$ for all $\mathrm{i}$.

While investors may well not have done rigorous analysis to estimate $\mathrm{k}$, it is not unreasonable to expect that they can produce a necessary hurdle rate for the proposed equity investment.

Assuming that $\mathrm{k}$ is constant for all $\mathrm{i}$ will depend upon, among other things, how the MFI will use the proceeds of the equity financing. If the MFI will use the funds to expand its current lending and operating activities, it is reasonable to work with $\mathrm{k}_{\mathrm{i}}=\mathrm{k}$ for all i. Given the debt financing already being employed by the MFI, it is probable that its 
debt to equity ratio would remain relatively constant looking forward. If, however, the MFI will employ the new capital to retire debt through time, it will be necessary to adjust the required expected return based on the pro forma debt ratio, which will change materially through time due to the debt repayments. This second scenario is analogous to the standard venture capital (VC) environment wherein the enterprise is intentionally over-levered prior to the VC equity capital commitment. In this case, all cash flows generated during the early years of the project are used to pay down debt in order to move the debt to equity ratio into a more normal range. Since the debt ratio will change on a year-to-year basis, $\mathrm{k}$ will have to change in order to reflect the changes in financial leverage. Refer to the Baldwin (2001) references for the relevant VC analysis.

To estimate $C F E_{i}$ for all $\mathrm{i}$, the MFI will use pro forma operating and financial data. It is important to understand that the cash flows required are not the Free Cash Flows (FCF) typically prepared by financial analysts. FCFs represent cash flows that are available to both debt holders and equity holders. To produce equity cash flows, it is necessary to include debt-related cash flows normally not included in FCF, namely, interest expense cash outflows, cash outflows for pro forma debt retirements, and cash inflows from any pro forma debt issuance. So, on a period-by-period basis, the projected equity cash flow statement would be:

Net Income

+ Depreciation

- Increase in Net Working Capital

-Gross Capital Expenditures

Cash Flow Available for Debt and Equity

- Debt Repayment

+ New Debt Issues

\section{$C F E$}

It is important to begin the $C F E$ calculation with Net Income, not EBIT (earnings before interest and taxes) in order to include interest payments on existing and any newly issued debt. Also, as the MFI progresses through Stage IV in its development, it may be subject to taxes in some jurisdictions. If the activities of the MFI are non-taxable, simply work with a tax rate of $0 \%$. Adding back depreciation to Net Income recognizes that depreciation is a non-cash expense. The analysis also captures the necessary cash reinvestment back into the MFI with the Net Working Capital and Capital Expenditure accounts. The resultant cash flow is available for debt principal repayments, and would be augmented by any new debt issues. As we have suggested, in many VC situations, all cash flow would initially be used to retire existing debt in order to reduce the high debt to equity ratio, but we do not require the MFI to do so. It is the pro forma package of CFEs that the MFI equity investor will use in the NPV analysis.

In theory, the equity investor will own all $C F E s$ to perpetuity. For analytical purposes, the analyst will explicitly project some finite number of CFEs (say, 5 to 10 
years worth) and estimate a terminal value at the end of the pro forma period. This terminal value is, in essence, the PV of all remaining CFEs to perpetuity. Borrowing from the mergers and acquisitions (M\&A) literature, see Fruhan (1993), we offer two alternatives to estimate $\mathrm{TV}_{\mathrm{N}}$, the terminal value at time $\mathrm{N}$, which corresponds to the end of the formal projection period:

(1) If it is reasonable to project that CFEs will remain constant after time N, then

$$
T V_{N}=\frac{C F E_{N}}{k}
$$

Under this assumption, the remaining cash flows are a perpetuity. It is simply the present value of the perpetuity. As Fruhan (1993) points out, it may be preferable to work with Net Income (N.I.) at time $\mathrm{N}$ instead of $C F E_{N}$. Under a zero growth assumption, it may be reasonable to project that no additional working capital investments will be required and that gross capital investments will equal depreciation in order to simply maintain net fixed assets at a constant level. In that case,

$$
\mathrm{TV}_{\mathrm{N}}=\frac{N \cdot I \cdot \cdot_{N}}{k}
$$

(2) If the CFEs are expected to grow at a constant rate $g$ after time $\mathrm{N}$ (maybe because the operations of the MFI are expected to expand), the Gordon constant growth model can be employed, see Brealey and Myers (2001),

$$
\mathrm{TV}_{\mathrm{N}}=\frac{C F E_{N} \mathbf{C}^{-}}{k-g}
$$

The M\&A literature also offers procedures based on either earnings or book value multiples, but these would be extremely difficult to apply here. Since no comparable publicly traded MFIs would exist, the necessary multiples would be unavailable.

Our equity investor is now ready to perform either an NPV or IRR analysis.

NPV Analysis:

$$
N P V=-E_{0}+\frac{C F E_{1}}{\left(+k^{\mathrm{T}}\right.}+\cdots+\frac{C F E_{N}}{\left(+k^{\mathrm{N}}\right.}+\frac{T V_{N}}{\left(+k^{\mathrm{N}}\right.}
$$

As before, if $\mathrm{NPV}<0,|N P V|$ or $\frac{|N P V|}{E_{0}}$ captures the social investment being made. 
IRR Analysis:

$$
N P V=0=-E_{0}+\frac{C F E_{1}}{\left(+I R R^{\top}\right.}+\cdots+\frac{C F E_{N}}{\left(+I R R^{\mathbf{N}}\right.}+\frac{T V_{N}}{\left(+I R R^{\mathrm{N}}\right.}
$$

In a manner similar to the above, if IRR $<\mathrm{k}, \mathrm{k}$-IRR represents a measure of the social investment being made.

\section{SUMMARY AND CONCLUSION}

The purpose of this paper has been to review financing sources commonly used in microfinance, and to outline financial analyses that MFIs might use in approaching potential equity investors. These proposed financial procedures, while quite common corporate techniques in well-developed countries, have not been widely applied in microfinance. While this may partially be attributed to the lack of comprehensive financial and operating data in MFIs, most providers of donor and grant funding have been satisfied to concentrate on the social benefits of their investments. We have argued that, if mainstream investors are to become investors in microfinance projects, they will likely require financial analyses similar to those used for their for-profit investing activities.

These equity investors will be concerned with the present value of the cash flows they expect to receive from the microfinance investment. This thinking is quite analogous to an equity investor "valuing" his/her stock holdings as the present value of the dividend stream expected. Even if the microfinance equity investor does not expect to earn the full risk adjusted required expected return on the microfinance investment, he/she will want a numerical estimate of the shortfall. In addition to providing the means to estimate this shortfall, we have argued that this shortfall can measure the magnitude of the socially beneficial donation that the investor is implicitly making as part of the equity investment.

If our proposal is to be implemented, much work remains to be done. In this paper, we have simply provided an overview of techniques that could be applied. For example, we have not addressed, but are aware of, the difficulties that would arise in data collection and parameter estimation. Note that similar considerations are material even in the corporate setting when well-developed public capital markets exist. On the other hand, it is our hope that this paper can set the stage for a dialogue between MFI managers and potential equity investors. 


\section{Bibliography}

Baldwin, C. (2001). "Technical Note on LBO Valuation (A)", Harvard Business School Case, 9-902-004, Boston, MA, USA.

Baldwin, C. (2001). "Technical Note on LBO Valuation (B)", Harvard Business School Case, 9-902-005, Boston, MA, USA.

Bass, J. (2000). “Innovations in Microfinance”, Technical note No. 7, Bamako: Mali.

Brealey, R.A. and S.C. Myers (2000). "Principles of Corporate Finance", Irwin McGraw-Hill, New York, NY, USA.

Calvin, B. (2001). "Framework for Financing Sources" in An Introduction to Key Issues in Microfinance, on Microfinance Network website.

CGAP1 (1996). "Private Sector Involvement Working Group Discussion Paper for the September 1996 Meeting 13."

CGAP2 (2001). "Micro Rating and Assessment Fund", www.cgap.org

Chu, M. "Securitization of a Microenterprise Portfolio", Accion International, USA.

Fehr, D. W. (2003). Optimal Management of Research Projects in the Not-ForProfit Sector", Center for Financial Studies Working Paper No. 2003-01, Southern New Hampshire University.

Fruhan, W.E. (1993). "Note: Valuing a Business Acquisition Opportunity", Harvard Business School Case, 9-289-039, Boston, MA, USA.

Gadway, J. and M.G. O’Donnell (1996). “Financing Microenterprises and Rural Smallholders", draft.

Garber, C. (1997). "Private Investment as a Financing Source for Microcredit", in The North-South Agenda, 23: North-South Center, University of Miami.

Gibbons, David and Jennifer Meehan (2002). Financing microfinance for poverty reduction. In Daley-Harris (ed.) "Pathways out of Poverty: Innovations in microfinance for the poorest families.” Bloomfield, Connecticut: Kumarian Press.

Glaeser, E.L. and A. Schleifer (1998). "Not-for-Profit Entrepreneurs", unpublished Harvard University manuscript. 
Jensen, M.C. and W.H. Meckling (1976). "Theory of the Firm: Management Behavior, Agency Costs and Capital Structure", Journal of Financial Economics, 3, 305360 .

Kampala (1999). "How to regulate and supervise microfinance: key issues in an international perspective", Proceedings of the High-level Policy Workshop.

Hempel, G.H. and D.G. Simonson (1999). "Bank Management—Text and Cases" $5^{\text {th }}$ edition, New York: John Wiley \& Sons.

Hannig, A. and S. Wisniwski (eds) (1999). "Challenges of Microsavings Mobilization -Concepts and Views from the Field", Eschborn: Deutsche Gesellschaft fur Technische Zasummenarbeit (GTZ) GmbH.

Jackelen, H.R. and E. Rhyne (1991). "Toward a More Market-Oriented Approach to Credit and Savings for the Poor" in Small Enterprise Development, 2(4).

Otero, M. (1989). "Handful of Rice: Savings Mobilization by Microenterprise Programs and Perspectives for their Future", Accion International Monograph Series No. 3, Washington, DC: ACCION 1989.

Schmidt, R.H. and C.P. Zeitinger (1996). "Prospects, problems and Potential of Credit-Granting NGOs" in Journal of International Development, 8(2).

Silva, A. (1998). "Taking Equity in Microfinance - The PROFUND Experience" Second Annual Seminar on New Development Finance at the Goethe University of Frankfurt.

Pearce, D. (2002). Water, water everywhere, but not a drop to drink, Viewpoint, http://www.cgap.org

Wisniwski, S. "Microsavings Compared to Other Sources of Funds" in Hannig, A. and S. Wisniwski (eds) (1999). "Challenges of Microsavings Mobilization-Concepts and Views from the Field", Eschborn: Deutsche Gesellschaft fur Technische Zasummenarbeit (GTZ) GmbH.

Von Pischke, K.D. (1999). "Capital Enhancement Guarantees", posted on the DEVFINANCE Network. 